\title{
Molecular Investigations of the Effect of Thermal Manipulation During Embryogenesis on the Enzymatic Activity of Creatine Kinase and Lactate Dehydrogenase in Broiler Muscle
}

Euthor(s)

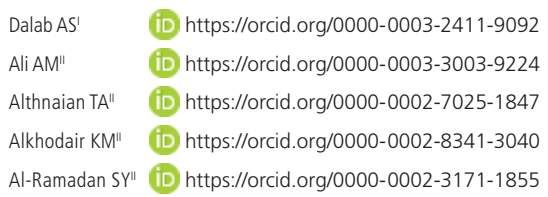

Department of Veterinary Medicine, College of Agriculture and Veterinary Medicine, An-Najah National University, P.O. Box 400, Al- Ahsa 31982 Saudi Arabia.

Department of Anatomy, College of Veterinary Medicine, King Faisal University, P.O. Box 400, AlAhsa 31982, Saudi Arabia.

\section{Mail Address}

Corresponding author e-mail address Ph.D. Abdelhafeed Sameer Dalab

Department of Veterinary Medicine, College of Agriculture and Veterinary Medicine, AnNajah National University, PO. Box 7 Nablus West Bank, Palestine.

Phone: +970 599356566

Email: a.dalab@najah.edu

\section{- Keywords}

Thermal Manipulation, Broiler

Embryogenesis, Creatine Kinase (CK), Lactate Dehydrogenase (LDH).

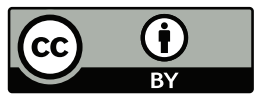

Submitted: 28/January/2021

Approved: 03/September/2021

\section{ABSTRACT}

Incubating temperature and timing or duration is critical to determine the optimum protocol of thermal manipulation (TM), which underlines muscle growth improvement. Therefore, the aim of the present study is to determine the optimum period of embryonic TM that may result in the improvement of pectoral and thigh muscle myogenesis. This is done by investigating the level of mRNA expression of creatine kinase $(\mathrm{CK})$ and lactate dehydrogenase (LDH). An additional goal is measuring the blood levels of CK and LDH as a biomarker of muscle injury due to the experimental thermal challenge on post-hatch day 35 . The study was conducted on 1,440 fertile eggs (Ross broilers) that were divided randomly and equally into a control group and four treatment groups (TM1, TM2, TM3, and TM4). The treatment groups were daily subjected to TM at $39^{\circ} \mathrm{C}$ for $18 \mathrm{~h}$ with $65 \%$ relative humidity $(\mathrm{RH})$ during embryonic days (EDs) $7-11,11-15,15-18$, and $7-18$, respectively. Among the thermally manipulated groups that were investigated, TM1 (ED 7-11) resulted in significant improvement of mRNA expression and enzymatic concentration of CK and LDH in muscle during embryogenesis, as compared to the control. Six hours of TC showed the highest significant CK and LDH expression and concentration levels in the control as compared to TM groups. Thus, the results of this study indicate that TM during ED 7-11 improves pectoral and thigh muscles' response to heat stress without adversely affecting their performance. This finding could be used by commercial breeders to enhance local broiler production.

\section{INTRODUCTION}

During embryogenesis, CK is expressed at a high level in developing embryonic striated muscle. It has been used as an early marker for skeletal myogenesis in chickens by maintaining a high ATP/ADP ratio (lyengar et al., 1983, Lyons et al., 1991). CK plays a role in cellular energy metabolism: it catalyzes the reversible transfer of high-energy phosphate from ATP to creatine, facilitating the storage of energy in the form of phosphocreatine (Hettling \& van Beek 2011). Another proposed function of CK is the transportation of energy from ATPproducing to ATP-consuming sites via a shuttle mechanism involving a mitochondrial and a myofibrillar isoform of CK (Hettling \& van Beek 2011). During embryogenesis, there is a high level of CK expression in the striated skeletal muscle, which is considered an early marker of striated skeletal muscle myogenesis in chickens (Lyons et al., 1991). Later authors proposed a biological role for CK in maintaining the ATP/ADP ratio. Thus, relatively high CK was thought to enhance ATPdemanding processes and reduce ADP-dependent functions (lyengar et al., 1983). LDH is a glycolytic enzyme that is found in almost every tissue, especially in skeletal muscle. It is involved in the final steps of glycolysis 
and glyconeogenesis, mediating the breakdown of pyruvate into lactate in the absence of oxygen (Wanda et al., 2013).

Pech-Waffenschmidt (1992) and Hsiao-Mei et al. (2016) reported that the abnormal appearance of CK and LDH in blood plasma could hint at specific muscle or organ damage. Abnormally increased plasma levels of CK and LDH were a consequence of the disruption of the function and permeability of the muscle cell membrane (Brancaccio et al., 2007). Additionally, Tang et al. (2013) reported that broiler exposure to high ambient temperatures significantly increases their plasma CK levels. Therefore, this study aims to investigate the effect of thermal manipulation during different durations (early, mid, late, and long-lasting) of broiler embryogenesis on mRNA gene expression of CK and LDH in both the pectoral and thigh muscles of embryos, as well as during the subsequent thermal challenge (TC) on post-hatch day 35. Additionally, it investigates the effect of thermal manipulation during embryogenesis on the plasma levels of CK and LDH released into the bloodstream after $1 \mathrm{~h}, 3 \mathrm{~h}$, and $6 \mathrm{~h}$ of TC on post-hatch day 35. The results of this research can be used in clinical biochemistry as a tool to assess the physiological response of broiler muscle to heat stress.

\section{MATERIALS AND METHODS}

All sampling, experimental incubation, and hatching management conditions were approved by King Faisal University's Animal Care and Use Committee (KFUACUC).

\section{Pre-egg Incubation Management}

A total of 1,700 Ross 708 broiler eggs were obtained from a local 36-week-old broiler flock (from Al-Ahsa, Saudi Arabia). The broken or abnormally small or large eggs (those weighing less than $58 \mathrm{~g}$ or more than $65 \mathrm{~g}$, respectively) were excluded before the first incubation day. 1,550 uniformly sized eggs remained.

\section{Egg Incubation and Thermal Manipulation Management}

The 1,550 uniformly sized eggs were incubated in semi-commercial incubators (type OVA-Easy 380 Advance Series II, Brinsea, Sandford, UK) at $37.8^{\circ} \mathrm{C}$ with $56 \%$ RH up to ED 7; egg candling was performed at ED 7 to exclude any dead embryos and infertile eggs, resulting in 1,440 fertile eggs. These fertile eggs were distributed randomly into five treatment groups; the first being the untreated control group that remained incubated at $37.8^{\circ} \mathrm{C}$ with $56 \% \mathrm{RH}$, whereas TM1, TM2,
TM3, and TM4 (with 288 eggs each) were subjected to $39{ }^{\circ} \mathrm{C}$ for $18 \mathrm{~h}$ with $65 \% \mathrm{RH}$ daily during ED 7-11, ED 11-15, ED 15-18, and ED 7-18, respectively.

\section{Hatching and Thermal Challenge Manage- ment}

All one-day-old hatched chicks were recorded and the field study was conducted at the Agricultural and Veterinary Research and Training Station at King Faisal University. Water and feed (ARASCO, Riyadh, Saudi Arabia) were supplied ad libitum to the chicks, and they were kept brooding at an initial house temperature of $31 \pm 1{ }^{\circ} \mathrm{C}$, which was reduced at an average of $0.2-0.3$ ${ }^{\circ} \mathrm{C}$ per day to achieve a final house temperature of $22 \pm$ $1^{\circ} \mathrm{C}$ by post-hatch day 24 . On post-hatch day 35 , chicks from each group were randomly and equally divided into two subgroups, naïve $(\mathrm{N})$ and thermal challenge (TC) $\left(100\right.$ chicks per group). Thermal challenge $\left(43.0^{\circ} \mathrm{C}\right.$ at $1 \mathrm{~h}, 3 \mathrm{~h}$, and $6 \mathrm{~h}$ intervals) was applied to the chicks of each TC subgroup, including the TC control subgroup, on post-hatch day 35 , while the naïve chicks of each subgroup were kept under regular conditions ( $22 \pm 1$ ${ }^{\circ} \mathrm{C}$ and $\left.50-60 \% \mathrm{RH}\right)$ in a separate room.

\section{Sampling Management}

Pectoral and thigh muscle samples from five control embryos and from each thermally manipulated group were collected at the end of ED 11, ED 15, and ED 18 for total RNA isolation of the embryonic CK and LDH (75 embryos, $n=5$ ). On post-hatch day 35 , humanely manual cervical dislocation (CD) euthanasia was conducted and confirmed by loss of any reflexes and musculoskeletal movements; pectoral and thigh muscle samples were collected from five chicks from each TC subgroup (at $1 \mathrm{~h}, 3 \mathrm{~h}$, and $6 \mathrm{~h}$ intervals of TC) and naïve chicks for total RNA isolation (100 chicks, $n=5$ ). Blood from the jugular vein from 10 chicks per group (control and treatment) was drawn at the beginning (Oh) and after $1 \mathrm{~h}, 3 \mathrm{~h}$, and $6 \mathrm{~h}$ of TC exposure (200 chicks, $n$ $=10)$ for measurement of blood plasma CK and LDH levels.

\section{RNA Isolation and Semi-quantitative Real- time RT-PCR Analyses}

mRNA expression levels of CK and LDH during embryogenesis and during subsequent thermal challenge (TC) at day 35 post-hatch were investigated and evaluated through semi-quantitative real-time RT-PCR analyses. Pectoral and thigh muscles were homogenized using a Bead Ruptor (24 Bead Mill Homogenizer OMNI, USA) and total RNA was extracted using the PureZOL TM RNA isolation method (BIO-RAD, 
Catalog \#732-6890, Hercules, CA, USA). DNA was removed using DNase I kit (Ambion), and RNA samples were checked for concentration and purity (260:280nm absorbency) (Synergy ${ }^{\mathrm{TM}} \mathrm{Mx}$ Monochromator-Based Multi-Mode Microplate ReaderBio-Tek.USA). RNA $(2 \mu \mathrm{g})$ was reverse-transcribed to CDNA in a reaction mixture using the iscriptc DNA synthesis kit (BIO-RAD, Catalog \#170-8890, Hercules, CA, USA).

The semi-quantitative real-time CFX96 Touch $^{\text {TM }}$ Realtime PCR (BIO-RAD, Hercules, CA, USA) was performed using the ssoAdvanced ${ }^{\mathrm{TM}}$ SYBR Green Supermix kit (BIO-RAD, Catalog \#170-5270, Hercules, CA, USA). The $20 \mu$ l reaction mix was prepared from $10 \mu \mathrm{l}$ of master mix; $2 \mu \mathrm{l}$ forward primer $\mathrm{pM} / \mu \mathrm{l} ; 2 \mu \mathrm{l}$ reverse primer $\mathrm{pm} / \mu \mathrm{l}$ (Table 1 ); $2 \mu \mathrm{l}$ cDNA of the sample; and $4 \mu \mathrm{l}$ of nuclease-free water. Cycling parameters were $95^{\circ} \mathrm{C}$ for $1 \mathrm{~m}$ and 40 cycles of $95^{\circ} \mathrm{C}$ for $10 \mathrm{~s}$, followed by $30 \mathrm{~s}$ at $60^{\circ} \mathrm{C}$ and $72^{\circ} \mathrm{C}$ for $10 \mathrm{~s}$, with final melting at $95^{\circ} \mathrm{C}$ for 20s. Triplicates from each cDNA were analyzed, fluorescence emission was detected, and relative quantification was calculated automatically according to GAPDH and ACTIN-1 Housekeeping genes.

\section{Biochemical Analysis of CK and LDH}

Chicks' responses to TC were evaluated by determination of plasma CK and LDH at the beginning of TC (Oh) and after $1 \mathrm{~h}, 3 \mathrm{~h}$, and $6 \mathrm{~h}$ of TC in naïve and TC subgroups. Plasma was isolated through centrifugation of blood samples at 3,000rpm for $10 \mathrm{~m}$ and was then stored at $-20^{\circ} \mathrm{C}$ until further analysis. A commercial ELISA kit was used for the determination of CK (MBS269755) and LDH (MBS263022) (Mybiosource, California, San Diego, USA) on ELISA reader (Synergy ${ }^{\mathrm{TM}} \mathrm{Mx}$ Monochromator-Based Multi-Mode Microplate Reader Bio-Tek. USA). The concentration results of CK and LDH were calculated according to the manufacturer's instruction protocols.

\section{Statistical Analysis}

The data for mRNA gene expressions and concentrations of CK and LDH was expressed as means \pm SE.

Table 1 - Oligonucleotides for gene expression analysis.

\begin{tabular}{|c|c|c|c|}
\hline Primers & Sequence & $\begin{array}{c}P C R \\
\text { Product Size }\end{array}$ & $\begin{array}{l}\text { GenBank } \\
\text { Reference }\end{array}$ \\
\hline \multirow[t]{2}{*}{ CK } & F-5-GGAGTTCAAGGGCCGCTATT-3 & \multirow{2}{*}{$190 \mathrm{bp}$} & \multirow{2}{*}{ NM_205507.1 } \\
\hline & R-5-ATTCACCCACACCAGGAACG-3 & & \\
\hline \multirow[t]{2}{*}{ LDH } & F-5-GCCGGCAGTACACCATGTC -3 & \multirow{2}{*}{$122 \mathrm{bp}$} & \multirow{2}{*}{ NM_205284.1 } \\
\hline & R-5-GGCACAAGCCATTCCAACTG-3 & & \\
\hline \multirow[t]{2}{*}{ GAPDH } & F-5-GTGTTATCATCTCAGCTCCCTCAG-3 & \multirow{2}{*}{$176 \mathrm{bp}$} & \multirow{2}{*}{ FJ_217667 } \\
\hline & R-5-GGTCATAAGACCCTCCACAATG-3 & & \\
\hline \multirow[t]{2}{*}{ ACTA1 } & F-5-CCATCGGCAATGAGCGTTTC-3 & \multirow{2}{*}{$195 \mathrm{bp}$} & \multirow{2}{*}{ NM_001031063.1 } \\
\hline & R-5-GCATGCGGTCAGCAATACCT-3 & & \\
\hline
\end{tabular}

A two-way ANOVA test and an all-pairs Bonferroni test were applied to compare the different parameters in each treatment group using the IBM SPSS Statistics 20 software (IBM, Chicago, USA). Differences were considered significant at $p<0.05$.

\section{RESULTS}

\section{CK and LDH mRNA Expression of Pectoral and Thigh Muscle at Embryonic Days (EDs) 11,15 , and 18}

On ED 11, the thermal manipulation of TM1 and TM4 from ED 7 to ED 11 resulted in a higher significant increase in mRNA expression of CK and LDH in both pectoral and thigh muscles as compared to the control group. The highest significant expression values of CK and $\mathrm{LDH}$ were observed in the pectoral muscles of TM1 and TM4 rather than the thigh muscles (Table 2).

On ED 15, the thermal manipulation of TM2 from ED 11 to ED 15 resulted in significant increase in mRNA expressions of CK and LDH in pectoral muscles and thigh muscles as compared to the control (Table 2). On the other hand, TM1 and TM4, which were thermally manipulated during ED 7-11, maintained increased mRNA expression of CK with no significant increases in mRNA expression of LDH in pectoral and thigh muscles in comparison to the control (Table 2).

On ED 18, the thermal manipulation of TM3 from ED 15 to ED 18 was found to increase pectoral and thigh muscles' mRNA expression of CK and LDH in comparison to control. Additionally, the pectoral mRNA expressions of CK values for TM1, TM2, and TM3 on ED 18 were significantly higher when compared to those of TM4 and the control. For thigh muscles, there were no significant differences in mRNA expression of CK values among TM1, TM2, and the control group, whereas there was significantly higher mRNA expression of LDH values in all treatment groups as compared to the control group.

The results of the relative normalized comparative gene study of mRNA levels of CK and LDH in both pectoral and thigh muscles during embryogenesis are shown in Table 3. The results show that the highest gene expressions (upregulations) were observed in early embryogenesis, while the lowest gene expression was observed in ED 1518. Hence, in the early and middle thermal manipulation for TM1 (ED 7-11), TM2 (ED 11-15), and TM4 (ED 7-11), the results show that there was upregulation expression (significantly increased expression) of CK 
Table 2 - Relative normalized expression of mRNA levels of CK and LDH in pectoral and thigh muscles during embryogenesis.

\begin{tabular}{|c|c|c|c|c|c|c|c|c|c|}
\hline \multirow{4}{*}{ Target } & \multicolumn{9}{|c|}{ Time (Age) } \\
\hline & \multicolumn{3}{|c|}{ ED 11} & \multicolumn{3}{|c|}{ ED 15} & \multicolumn{3}{|c|}{ ED 18} \\
\hline & \multirow[t]{2}{*}{ Sample } & \multicolumn{2}{|c|}{ Expression (Fold) } & \multirow[t]{2}{*}{ Sample } & \multicolumn{2}{|c|}{ Expression (Fold) } & \multirow[t]{2}{*}{ Sample } & \multicolumn{2}{|c|}{ Expression (Fold) } \\
\hline & & $\begin{array}{l}\text { Pectoral } \\
\text { Muscle }\end{array}$ & $\begin{array}{l}\text { Thigh } \\
\text { Muscle }\end{array}$ & & $\begin{array}{l}\text { Pectoral } \\
\text { Muscle }\end{array}$ & Thigh Muscle & & $\begin{array}{l}\text { Pectoral } \\
\text { Muscle }\end{array}$ & Thigh Muscle \\
\hline \multirow{7}{*}{ CK } & Control* & $1.0 \pm 0.4 a$ & $1.0 \pm 0.3 a$ & Control* & $1.0 \pm 0.1 a$ & $1.0 \pm 0.2 \mathrm{a}$ & Control* & $1.0 \pm 0.3 a$ & $1.0 \pm 0.2 \mathrm{a}$ \\
\hline & $\mathrm{TM}_{1}$ & $16.64 \pm 2.5 b$ & $2.36 \pm 0.2 b$ & $\mathrm{TM}_{1}$ & $2.15 \pm 0.1 b$ & $1.96 \pm 0.4 a$ & $\mathrm{TM}_{1}$ & $1.92 \pm 0.2 b$ & $0.47 \pm 0.1 a$ \\
\hline & $\mathrm{TM}_{2}$ & ------- & ------- & $\mathrm{TM}_{2}$ & $2.71 \pm 0.9 b$ & $1.89 \pm 0.6 b$ & $\mathrm{TM}_{2}$ & $1.73 \pm 0.7 b$ & $0.91 \pm 0.1 \mathrm{a}$ \\
\hline & $\mathrm{TM}_{3}$ & ------- & ------- & $\mathrm{TM}_{3}$ & ------- & ------- & $\mathrm{TM}_{3}$ & $2.73 \pm 0.3 c$ & $1.77 \pm 0.3 a$ \\
\hline & $\mathrm{TM}_{4}$ & $14.64 \pm 3.0 c$ & $2.84 \pm 0.4 b$ & $\mathrm{TM}_{4}$ & $2.55 \pm 0.4 b$ & $1.79 \pm 0.1 b$ & $\mathrm{TM}_{4}$ & $1.52 \pm 0.4 a$ & $1.63 \pm 0.4 b$ \\
\hline & \multicolumn{3}{|c|}{ ED 11} & \multicolumn{3}{|c|}{ ED 15} & \multicolumn{3}{|c|}{ ED 18} \\
\hline & Sample & \multicolumn{2}{|c|}{ Expression (Fold) } & Sample & \multicolumn{2}{|c|}{ Expression (Fold) } & Sample & \multicolumn{2}{|c|}{ Expression (Fold) } \\
\hline \multirow{6}{*}{ LDH } & & $\begin{array}{c}\text { Pectoral } \\
\text { Muscle }\end{array}$ & $\begin{array}{l}\text { Thigh } \\
\text { Muscle }\end{array}$ & & $\begin{array}{c}\text { Pectoral } \\
\text { Muscle }\end{array}$ & Thigh Muscle & & $\begin{array}{l}\text { Pectoral } \\
\text { Muscle }\end{array}$ & Thigh Muscle \\
\hline & Control* & $1.0 \pm 0.5 a$ & $1.0 \pm 0.2 a$ & Control* & $1.0 \pm 0.1$ & $1.0 \pm 0.2$ & Control* & $1.0 \pm 0.3 a$ & $1.0 \pm 0.2 \mathrm{a}$ \\
\hline & $\mathrm{TM}_{1}$ & $1.86 \pm 0.2 b$ & $2.0 \pm 0.1 b$ & $\mathrm{TM}_{1}$ & $0.72 \pm 0.1 a$ & $0.34 \pm 0.09 b$ & $\mathrm{TM}_{1}$ & $1.05 \pm 0.1 a$ & $2.60 \pm 0.2 b$ \\
\hline & $\mathrm{TM}_{2}$ & ------- & ------- & $\mathrm{TM}_{2}$ & $1.83 \pm 0.3 a$ & $1.73 \pm 0.2 a$ & $\mathrm{TM}_{2}$ & $1.20 \pm 0.6 a$ & $2.00 \pm 0.3 b$ \\
\hline & $\mathrm{TM}_{3}$ & ------- & ------- & $\mathrm{TM}_{3}$ & ------- & ------- & $\mathrm{TM}_{3}$ & $2.73 \pm 0.4 b$ & $1.62 \pm 0.3 c$ \\
\hline & $\mathrm{TM}_{4}$ & $1.89 \pm 0.3 a$ & $2.08 \pm 0.7 b$ & $\mathrm{TM}_{4}$ & $0.80 \pm 0.1 \mathrm{a}$ & $0.30 \pm 0.03 b$ & $\mathrm{TM}_{4}$ & $1.01 \pm 0.3 a$ & $2.22 \pm 0.5 b$ \\
\hline
\end{tabular}

Control $=37.8^{\circ} \mathrm{C} ; \mathrm{TM} 1=$ thermal manipulation during $\mathrm{ED} 7-11$ at $39^{\circ} \mathrm{C}$ for $18 \mathrm{~h} ; \mathrm{TM} 2=$ thermal manipulation during ED $11-15$ at $39^{\circ} \mathrm{C}$ for $18 \mathrm{~h} ; \mathrm{TM} 3=$ thermal manipulation during ED $15-18$ at $39^{\circ} \mathrm{C}$ for $18 \mathrm{~h} ; \mathrm{TM} 4=$ thermal manipulation during ED $7-18$ at $39^{\circ} \mathrm{C}$ for $18 \mathrm{~h}$; a-c within the same day means that $\pm \mathrm{SD}$ with different superscripts differ significantly $(p<0.05)$. ( ${ }^{*}$ Compared to the control of each embryonic day).

in pectoral muscles more than in thigh muscles when compared to the control (Table 3). Moreover, the results obtained from this study show that the highest gene expressions (upregulations) of LDH were found in early embryogenesis only, and the lowest gene expression was observed for ED 11-18. Results from the control show downregulation expressions (significantly lowered expression) of CK in both pectoral and thigh muscles when compared to TM1.

\section{Effect of Thermal Challenge (TC) on the Expression of CK and LDH in Naïve and Chicken Subjected to $43^{\circ} \mathrm{C}$ for $1 \mathrm{~h}, 3 \mathrm{~h}$, and $6 \mathrm{~h}$ Intervals on Post-hatch Day 35}

On post-hatch day 35, CK mRNA expression in the pectoral muscle of naïve chicks was significantly higher in TM1, TM2, and TM3 as compared to TM4 and the control. In naïve thigh muscle, CK mRNA expression

Table 3 - Gene study of relative normalized expression of mRNA of CK and LDH in pectoral and thigh muscles during embryogenesis.

\begin{tabular}{|c|c|c|c|c|c|c|c|c|c|}
\hline \multirow{4}{*}{ Target } & \multicolumn{9}{|c|}{ Time (Age) } \\
\hline & \multicolumn{3}{|c|}{ ED 11} & \multicolumn{3}{|c|}{ ED 15} & \multicolumn{3}{|c|}{ ED 18} \\
\hline & \multirow[t]{2}{*}{ Sample } & \multicolumn{2}{|c|}{ Expression (Fold) } & \multirow[t]{2}{*}{ Sample } & \multicolumn{2}{|c|}{ Expression (Fold) } & \multirow[t]{2}{*}{ Sample } & \multicolumn{2}{|c|}{ Expression (Fold) } \\
\hline & & $\begin{array}{l}\text { Pectoral } \\
\text { Muscle }\end{array}$ & $\begin{array}{l}\text { Thigh } \\
\text { Muscle }\end{array}$ & & $\begin{array}{l}\text { Pectoral } \\
\text { Muscle }\end{array}$ & Thigh Muscle & & $\begin{array}{l}\text { Pectoral } \\
\text { Muscle }\end{array}$ & Thigh Muscle \\
\hline \multirow{7}{*}{ CK } & Control* & $1.0 \pm 0.4$ & $1.0 \pm 0.3$ & Control & $4.77 \pm 0.6$ & $0.93 \pm 0.6$ & Control & $2.90 \pm 0.8$ & $0.86 \pm 0.2$ \\
\hline & $\mathrm{TM}_{1}$ & $16.64 \pm 2.5$ & $2.36 \pm 0.2$ & $\mathrm{TM}_{1}$ & $11.79 \pm 0.4$ & $1.82 \pm 0.3$ & $\mathrm{TM}_{1}$ & $5.75 \pm 0.6$ & $0.40 \pm 0.1$ \\
\hline & $\mathrm{TM}_{2}$ & $1.40 \pm 0.8$ & $1.04 \pm 0.2$ & $\mathrm{TM}_{2}$ & $7.81 \pm 0.4$ & $1.11 \pm 0.5$ & $\mathrm{TM}_{2}$ & $4.77 \pm 0.2$ & $0.74 \pm 0.1$ \\
\hline & $\mathrm{TM}_{3}$ & $1.34 \pm 0.5$ & $1.24 \pm 0.4$ & $\mathrm{TM}_{3}$ & $6.40 \pm 0.6$ & $1.91 \pm 0.3$ & $\mathrm{TM}_{3}$ & $6.36 \pm 0.8$ & $1.31 \pm 0.2$ \\
\hline & $\mathrm{TM}_{4}$ & $14.64 \pm 3.0$ & $2.84 \pm 0.4$ & $\mathrm{TM}_{4}$ & $12.49 \pm 0.8$ & $1.73 \pm 0.1$ & $\mathrm{TM}_{4}$ & $3.81 \pm 0.8$ & $1.41 \pm 0.3$ \\
\hline & \multicolumn{3}{|c|}{ ED 11} & \multicolumn{3}{|c|}{ ED 15} & \multicolumn{3}{|c|}{ ED 18} \\
\hline & Sample & \multicolumn{2}{|c|}{ Expression (Fold) } & Sample & \multicolumn{2}{|c|}{ Expression (Fold) } & Sample & \multicolumn{2}{|c|}{ Expression (Fold) } \\
\hline \multirow{6}{*}{ LDH } & & $\begin{array}{l}\text { Pectoral } \\
\text { Muscle } \\
\end{array}$ & $\begin{array}{c}\text { Thigh } \\
\text { Muscle }\end{array}$ & & $\begin{array}{l}\text { Pectoral } \\
\text { Muscle }\end{array}$ & Thigh Muscle & & $\begin{array}{l}\text { Pectoral } \\
\text { Muscle }\end{array}$ & Thigh Muscle \\
\hline & Control* & $1.0 \pm 0.5$ & $1.0 \pm 0.2$ & Control & $0.32 \pm 0.02$ & $0.23 \pm 0.02$ & Control & $0.04 \pm 0.01$ & $0.05 \pm 0.01$ \\
\hline & $\mathrm{TM}_{1}$ & $1.86 \pm 0.2$ & $2.0 \pm 0.1$ & $\mathrm{TM}_{1}$ & $0.26 \pm 0.09$ & $0.09 \pm 0.01$ & $\mathrm{TM}_{1}$ & $0.12 \pm 0.02$ & $0.13 \pm 0.01$ \\
\hline & $\mathrm{TM}_{2}$ & $0.92 \pm 0.2$ & $0.75 \pm 0.2$ & $\mathrm{TM}_{2}$ & $0.29 \pm 0.09$ & $0.20 \pm 0.03$ & $\mathrm{TM}_{2}$ & $0.04 \pm 0.01$ & $0.09 \pm 0.01$ \\
\hline & $\mathrm{TM}_{3}$ & $0.41 \pm 0.1$ & $0.88 \pm 0.2$ & $\mathrm{TM}_{3}$ & $0.18 \pm 0.02$ & $0.04 \pm 0.02$ & $\mathrm{TM}_{3}$ & $0.06 \pm 0.01$ & $0.10 \pm 0.01$ \\
\hline & $\mathrm{TM}_{4}$ & $1.89 \pm 0.3$ & $2.08 \pm 0.7$ & $\mathrm{TM}_{4}$ & $0.02 \pm 0.01$ & $0.07 \pm 0.01$ & $\mathrm{TM}_{4}$ & $0.06 \pm 0.01$ & $0.11 \pm 0.03$ \\
\hline
\end{tabular}

Control $=37.8^{\circ} \mathrm{C} ; \mathrm{TM} 1=$ thermal manipulation during $\mathrm{ED} 7-11$ at $39^{\circ} \mathrm{C}$ for $18 \mathrm{~h} ; \mathrm{TM} 2=$ thermal manipulation during $\mathrm{ED} 11-15$ at $39^{\circ} \mathrm{C}$ for $18 \mathrm{~h} ; \mathrm{TM} 3=$ thermal manipulation during ED $15-18$ at $39^{\circ} \mathrm{C}$ for $18 \mathrm{~h} ; \mathrm{TM} 4=$ thermal manipulation during ED $7-18$ at $39^{\circ} \mathrm{C}$ for $18 \mathrm{~h}$; a-c within the same day means that $\pm S D$ with different superscripts differ significantly $(p<0.05)$. ( ${ }^{*}$ As compared to the control of pectoral and thigh muscle of ED 11 pectoral-to-pectoral and thigh-to-thigh). 
Dalab AS, Ali AM, Althnaian TA, Alkhodair KM, Al-Ramadan SY

\section{Molecular Investigations of the Effect of Thermal Manipulation During Embryogenesis on the Enzymatic Activity of Creatine Kinase and Lactate Dehydrogenase in Broiler Muscle}

was found after $6 \mathrm{~h}$ of TC as compared to $1 \mathrm{~h}$ and $3 \mathrm{~h}$ of TC (Figure 1).

In pectoral muscle, $1 \mathrm{~h}, 3 \mathrm{~h}$, and $6 \mathrm{~h}$ of TC had no significant effect on mRNA expression of LDH in all treatment groups when compared to the control $(1 \mathrm{~h}$, $3 \mathrm{~h}$, and $6 \mathrm{~h}$ of TC) (Figure 1). In thigh muscle, only in TM2 did the $1 \mathrm{~h}$ and $3 \mathrm{~h}$ of thermal challenge induce mRNA expression of LDH higher than those of the $1 \mathrm{~h}$ and 3h-TC control group, and more than the other treatment groups; it also did so in TM2 naïve chicks. Six hours of thermal challenge influenced the mRNA expression of LDH in the control, TM2, and TM3 at a higher significant expression level than those of the $6 \mathrm{~h}$ TC TM1 group. Moreover, 6h of TC showed a higher significant difference in mRNA expression of LDH in the control, TM2, TM3, and TM4 when compared to those of the control (naïve) and $1 \mathrm{~h}$ and $3 \mathrm{~h}$ of TC (Figure 2).
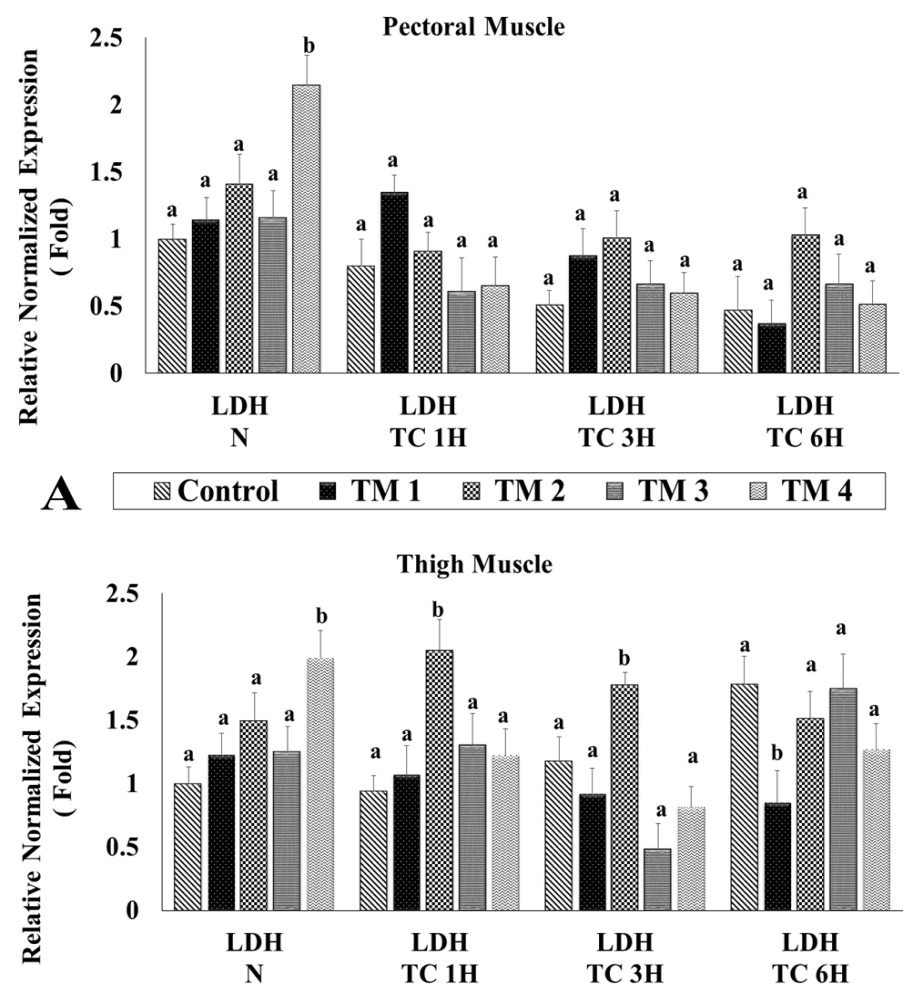

B

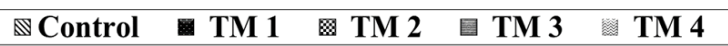

Figure $\mathbf{2}$ - The effect of thermal challenge (TC) on the mRNA level of LDH in (A) pectoral and (B) thigh muscles in TC chicks subjected to thermal challenge at $43^{\circ} \mathrm{C}$ for $1 \mathrm{~h}, 3 \mathrm{~h}$ and 6 hours at post-hatch day 35. N: Naive chicks. a-c folds with different superscripts differ significantly $(p<0.05)$.

\section{Effect of Thermal Challenge (TC) at $43^{\circ} \mathrm{C}$ on Plasma Levels of CK and LDH}

On post-hatch day $35,1 \mathrm{~h}$ and $3 \mathrm{~h}$ of TC caused significant increases in plasma levels of $\mathrm{CK}$ in the control, TM1, TM2, and TM3 as compared to those of naïve groups with a higher significant value in TM1 (Table 4). Meanwhile, $1 \mathrm{~h}$ and $3 \mathrm{~h}$ of TC caused 
significant reduction in CK levels in TM4 as compared to those of the TM4 naïve group. Additionally, the control group showed a significant increase in CK levels from $1 \mathrm{~h}$ of $\mathrm{TC}$ to $6 \mathrm{~h}$ when compared to those of the control naïve group. Furthermore, TC groups showed no significant differences in CK levels after 6 hours of TC in all treatment groups that ranged between $50.04-56.66 \mathrm{ng} / \mathrm{ml}$, while the highest value was recorded in the control $(62.98 \mathrm{ng} / \mathrm{ml})$ after $6 \mathrm{~h}$ of TC (Table 4).

Furthermore, $1 \mathrm{~h}$ of TC caused a significant reduction in LDH levels in TM2, TM3, and TM4 as compared to those of the naïve groups. Moreover, TC during the first hour had no significant differences in LDH levels for the control and TM1 as compared to their naïve groups (Table 4), and 3h of TC influenced LDH levels, showing significant increases in the control, TM3, and TM4 as compared to those obtained with $3 \mathrm{~h}$ of TC for TM1 and TM2. After 3h of TC, TM1 and TM2 showed no significant difference in LDH levels when compared to their $1 \mathrm{~h}$-TC groups. Moreover, the observation after 6h of TC showed a significant reduction in LDH levels in TM1 when compared to the other treatment groups after $6 \mathrm{~h}$ of TC. The highest value was recorded in the control after $6 \mathrm{~h}$ of TC as compared to the other treatment groups (Table 4).

Table 4 - The effect of TC at $43^{\circ} \mathrm{C}$ for 6 hours on post-hatch day 35 on plasma levels of CK and LDH $(n=10)$.

\begin{tabular}{|c|c|c|c|c|c|}
\hline CK (ng/ml) & Control & $\mathrm{TM}_{1}$ & $\mathrm{TM}_{2}$ & $\mathrm{TM}_{3}$ & $\mathrm{TM}_{4}$ \\
\hline $\mathrm{N}$ & $45.19 \pm 3.07^{\mathrm{aw}}$ & $50.58 \pm 0.93^{b w}$ & $51.87 \pm 4.61^{\mathrm{bw}}$ & $49.98 \pm 2.42^{b w}$ & $64.32 \pm 3.54^{\mathrm{cw}}$ \\
\hline TC $1 \mathrm{~h}$ & $54.27 \pm 4.65^{a x}$ & $78.98 \pm 4.68^{b x}$ & $61.04 \pm 4.83^{c x}$ & $56.83 \pm 5.76$ ax & $59.89 \pm 4.49^{d x}$ \\
\hline TC 3h & $57.93 \pm 4.14^{\mathrm{ax}}$ & $70.07 \pm 1.96^{\text {by }}$ & $61.28 \pm 1.87^{\mathrm{x}}$ & $57.17 \pm 3.12^{\mathrm{ax}}$ & $58.91 \pm 2.92^{\mathrm{ax}}$ \\
\hline TC $6 h$ & $62.98 \pm 3.36^{\text {ay }}$ & $54.50 \pm 4.57^{\mathrm{bz}}$ & $50.04 \pm 5.01^{b w}$ & $50.10 \pm 2.49^{b y}$ & $56.66 \pm 5.76^{b x}$ \\
\hline $\mathrm{LDH}(\mathrm{ng} / \mathrm{ml})$ & Control & $\mathrm{TM}_{1}$ & $\mathrm{TM}_{2}$ & $\mathrm{TM}_{3}$ & $\mathrm{TM}_{4}$ \\
\hline $\mathrm{N}$ & $3.76 \pm 0.31^{\mathrm{aw}}$ & $2.82 \pm 0.46^{b w}$ & $3.75 \pm 0.52$ aw & $3.70 \pm 0.59 \mathrm{aw}$ & $3.60 \pm 0.34$ aw \\
\hline TC $1 \mathrm{~h}$ & $3.45 \pm 0.05 \mathrm{aw}$ & $2.77 \pm 0.54^{b w}$ & $3.18 \pm 0.46^{b x}$ & $2.48 \pm 0.08^{b x}$ & $2.83 \pm 0.24^{\mathrm{bx}}$ \\
\hline TC $3 \mathrm{~h}$ & $5.13 \pm 0.04 \mathrm{ax}$ & $2.68 \pm 0.46^{b w}$ & $3.17 \pm 0.44^{b x}$ & $4.09 \pm 0.47^{d w}$ & $4.28 \pm 0.64^{d y}$ \\
\hline TC 6h & $3.45 \pm 0.52 \mathrm{aw}$ & $2.14 \pm 0.20^{\mathrm{bx}}$ & $2.82 \pm 0.45^{\mathrm{c}}$ & $2.86 \pm 0.11^{c y}$ & $2.95 \pm 0.53^{\mathrm{c}}$ \\
\hline
\end{tabular}

Control $=37.8^{\circ} \mathrm{C} ; \mathrm{TM} 1=$ thermal manipulation during $\mathrm{ED} 7-11$ at $39^{\circ} \mathrm{C}$ for $18 \mathrm{~h} ; \mathrm{TM} 2=$ thermal manipulation during $\mathrm{ED} 11-15$ at $39^{\circ} \mathrm{C}$ for $18 \mathrm{~h} ; \mathrm{TM} 3=$ thermal manipulation during ED $15-18$ at $39^{\circ} \mathrm{C}$ for $18 \mathrm{~h} ; \mathrm{TM} 4=$ thermal manipulation during ED $7-18$ at $39^{\circ} \mathrm{C}$ for $18 \mathrm{~h} ; \mathrm{TC}=$ thermal challenge; a-e within rows means that \pm SD with different superscripts differ significantly $(p<0.05)$. $x-z$ between naïve and TC chicks within a group means that \pm SD with different superscripts differ significantly $(p<0.05)$.

\section{DISCUSSION}

This study shows that embryonic thermal manipulation has influenced the expression of CK for pectoral muscles more than for thigh muscles in TM1 and TM4 (ED 7-11). This level of expression might be related to the high level of ATP demand during pectoral myogenesis in comparison to that of thigh muscle. In the current study on post-hatch day 35, the highest significant mRNA expression of CK was in pectoral muscle in TM1, TM2, and TM3 when compared to TM4 and the control. Moreover, our results show that the mRNA expression of CK was higher in pectoral muscles than in thigh muscles (only in TM4 was there higher expression in the thigh). This may indicate that mRNA expressions of CK on post-hatch day 35 play a pivotal role in the temporal buffering of changes in ATP and ADP during pectoral muscle development more than thigh muscle development, thereby maintaining ATP homeostasis. Likewise, the data from Hettling \& van Beek (2011) emphasized the role of CK in energy metabolism. Later authors suggested a catalytic function for CK in the transferring of high-energy phosphate from ATP to creatine.
On the other hand, $\mathrm{TC}$ at $43^{\circ} \mathrm{C}$ for $6 \mathrm{~h}$ significantly lowered mRNA expression of CK in pectoral muscle for all treatment groups and even the control, as compared to their counterpart naïve groups. For thigh muscle, the mRNA expression of CK with $6 \mathrm{~h}$ of TC was significantly higher in TM3 and TM4. Additionally, thermal challenge significantly changed the CK enzyme activities in the chickens' serum from the beginning of TC until $6 \mathrm{~h}$ of exposure.

Exposure of broiler chickens to environmental stressors can lead to the release of CK into the circulation in response to changes in permeability of sarcolemma (Mitchell \& Sandercock 1994). Publications about the effect of high environmental temperatures on CK activity are not consistent, possibly due to the large variability of the enzymes (Melesse et al., 2011). Zheng et al. (2020) reported that serum CK was not significantly affected by the stress during broiler transportation. This was in agreement with previous study by Al-Zghoul, et al. (2015) that reported no significant effect on CK levels in broilers that were thermal manipulated during their embryogenesis. On the other hand, Sandercock et al. (2001) observed a significant increase in CK activity in broilers exposed to 
acute type of heat stress reflecting heat stress-induced myopathy. Similarly, Yalçin et al. (2009) reported that broiler exposure to daily heat stress can lead to increase in plasma CK activity. Additionally, Tang et al. (2018) reported an increase in CK levels following broiler exposure to heat stress $\left(42 \pm 1{ }^{\circ} \mathrm{C}\right.$ for $(0,1,3$, 5 , and $10 \mathrm{~h}$ ). This was in agreement with our finding for TC groups. TC caused a significant increase in serum CK level in the control, TM1, TM2, and TM3 in the first and third hours of TC as compared to naive groups with a higher value in TM1 (CK: 70-78ng/ml). Meanwhile, $6 \mathrm{~h}$ of TC showed significant differences in serum CK levels in all treatment groups with a higher value in the control (CK: $62.98 \mathrm{ng} / \mathrm{ml})$ as compared to those of TM1, TM2, TM3, and TM4. In other words, we observed lower mRNA expression in TC groups after 6h, especially in the control group with higher serum CK levels. This means that the control group has more stress after $6 \mathrm{~h}$ of TC when compared to all treatment groups. The increased serum CK levels in the control after $6 \mathrm{~h}$ of TC may be indicative of skeletal muscle damage or a consequence of a disruption in the function and permeability of the muscle cell membrane, as reported by Brancaccio et al. (2007).

Together, the plasma and mRNA gene expression of CK in our findings suggest that there was the reestablishment of homeostasis in response to TC in embryonic thermally manipulated chicks (ED 7-11 at $39^{\circ} \mathrm{C}$ for $18 \mathrm{~h}$ ) when compared to the control. Addtionally, their body requires reprogramming of metabolism and gene expression to shunt energy sources from growth-related biosynthetic processes to defense, acclimatization, or adaptation to heat stress. Therefore, the thermotolerance acquisition induced by TM1 was safe for broiler muscle tissues. More significantly, growth performance in TM1 (ED 7-11 to $39^{\circ} \mathrm{C}$ for $18 \mathrm{~h}$ ) was actually significantly improved over other treatment conditions compared to the control.

Jia et al. (2016) reported that embryonic development is directly affected by the environment, since fertilized eggs are independent from the maternal system. Moreover, Lindy \& Rajasalmi (1966) reported that incubation of chick embryos in a hypoxic environment causes an increase in the proportion of tissue LDH, whereas incubation in aerobic conditions decreases the proportional amount of LDH. This study shows that embryonic thermal manipulation increases mRNA expression of LDH in pectoral and/or thigh muscle in all treatment groups as compared to the control. This means that the LDH expressed may be related to the incubation of the embryos in a hypoxic environment condition during thermal manipulation (such as elevated incubation temperature $39^{\circ} \mathrm{C}$ for $18 \mathrm{~h}$ and high humidity rate (65\%)) which significantly lowers the oxygen conductance of the eggshell during these hypoxic environment conditions and subsequently causes an increase in the proportion of tissue LDH in pectoral and thigh muscles in TM groups as compared to the control.

Consequently, it may be that the adaptation of TM1 to the high incubation temperature of $39^{\circ} \mathrm{C}$ for $18 \mathrm{~h}$ and high humidity rate $(65 \%)$ in early development (ED 7-11) is associated with low metabolic oxygen demand in the tissue. Jia et al. (2016) reported that the adaptation of Tibetan chicken embryos to high altitude (low oxygen) may be associated with higher quantities of yolk in the egg and a low metabolic oxygen demand in the tissue, which illuminates the reasons why Tibetan chicken have higher hatchability with lower oxygen transport ability.

On post-hatch day 35, the highest significant mRNA expression of LDH was only in the pectoral and thigh muscles of TM4 as compared to the control. Moreover, our findings show that serum LDH levels were significantly higher in the control, TM2, TM3, and TM4 when compared to TM1. Together, mRNA gene expression and serum levels of LDH on posthatch day 35 indicate that there was myonecrosis in both pectoral and thigh muscles of these groups as compared to TM1. On the other hand, TC at $43^{\circ} \mathrm{C}$ for $6 \mathrm{~h}$ significantly lowers the mRNA expression of $\mathrm{LDH}$ in pectoral muscle for all treatment groups and even the control when compared to their counterpart naïve groups. In the thigh, mRNA expression of LDH was significantly higher in TM2, TM3, TM4, and even the control when compared with TM1 after 6 h of TC. Additionally, TC caused a significant decline in serum LDH levels in TM1 when compared to the control and other treatment groups. This decline started from the first hour of TC until the end of the exposure after $6 \mathrm{~h}$.

It seems that the control group did not cope with stress after 6 h of TC when compared to all treatment groups. The lower mRNA expression and lower plasma LDH levels in TM1 after $6 \mathrm{~h}$ of TC signify that TM1 adapted for a second time to the higher environmental heat stress $\left(43^{\circ} \mathrm{C}\right.$ for $\left.6 \mathrm{~h}\right)$, and that it can cope with heat stress without a negative impact on body performance.

According to Ward \& Peterson (1973), the increase in enzyme activity may be partly attributed to cellular damage as a direct consequence of heat stress. Therefore, plasma enzyme activities that are highly correlated with the ability to withstand heat stress 
may serve as genetic markers for the selection and development of a chicken more resistant to heat stress (Melesse et al., 2011).

It can be concluded that, among the various TM conditions that were investigated, TM1 treatment resulted in significant improvement of muscle physiological response to heat stress by lower CK and $\mathrm{LDH}$ during TC on post-hatch day 35 as compared to the control. The outcome of this research may improve broiler production efficiency and contribute to increased broiler chicken adaptation to environmental heat stress without negative impact on body performance.

\section{ACKNOWLEDGMENT}

The authors would like to thank King Faisal University's Deanship of Research for their financial support (Grant No. 182005).

\section{REFERENCES}

Al-Zghoul MB, El-Bahr SM, Al-Rukibat RK, Dalab AES, Althnaian TA, Alramadan SY. Biochemical and molecular investigation of thermal manipulation protocols during broiler embryogenesis and subsequent thermal challenge. BMC Veterinary Research 2015;11:292-301.

Bałaban J, Wierzbicki M, Zielińska M, Szczepaniak J, Sosnowska M, Daniluk $K$, et al. Effects of graphene oxide nanofilm and chicken embryo muscle extract on muscle progenitor cell differentiation and contraction. Molecules 2020;25(8).

Brancaccio P, Maffulli N, Limongelli FM. Creatine kinase monitoring in sport medicine. British Medical Bulletin 2007;81:209-230.

Hettling $\mathrm{H}$, van Beek JH. Analyzing the functional properties of the creatine kinase system with multiscale 'sloppy' modeling. PLOS Computational Biology 2011;7(8):e1002130.

Hsiao-Mei L, Der-Yuh L, Yan-Derh, Tsung-Pingh, Hsiu-Luan C, Cheng-Yung $L$, et al. Association of heat shock protein 70 gene polymorphisms with acute thermal tolerance, growth, and egg production traits of native chickens in Taiwan. Archives of Animal Breeding 2016;59:173-181.

lyengar MR, lyengar CW, Chen HY, Brinster RL, Bornslaeger E, Schultz RM. Expression of creatine kinase isoenzyme during oogenesis and embryogenesis in the mouse. Developmental Biology 1983;96(1):263268.

Jia CL, He LJ, Li PC, Liu HY, Wei ZH. Effect of egg composition and oxidoreductase on adaptation of Tibetan chicken to high altitude. Poultry Science 2016;95(7):1660-1665.

Kongas $\mathrm{O}$, and van Beek J. Creatine kinase in energy metabolic signaling in muscle. Nature Precedings; 2007. Available from: https://www.nature. com/articles/npre.2007.1317.1.

Lindy S, Rajasalmi M. Lactate dehydrogenase isozymes of chick embryo:response to variations of ambient oxygen tension. Science 1966;153(3742):1401-1403

Lyons GE, Muhlebach S, Moser A, Masood R, Paterson BM, Buckingham $\mathrm{ME}$, et al. Developmental regulation of creatine kinase gene expression by myogenic factors in embryonic mouse and chick skeletal muscle. Development 1991;113(3):1017-1029.
Melesse A, Maak S, Schmidt R, von Lengerken G. Effect of long-term heat stress on key enzyme activities and T3 levels in commercial layer hens. International Journal of Livestock Production 2011;2(7):107-116.

Mitchell MA, Sandercock DA. Age dependent changes in plasma creatine kinase activity in broiler. Proceedings of 9th European Poultry Conference Glasgow; 1994; Scotland. Andover : World's Poultry Science Association; 1994. p.266-267.

Pech-Waffenschmidt $\mathrm{V}$. The effect of heat stress conditions on performance, physiology and blood chemistry of laying hens of different feathering types and nutritional considerations to improve the heat resistance [dissertation]. Berlin (DE): Technical University; 1992.

Sandercock DA, Hunter RR, Nute GR, Mitchell MA, Hocking PM. Acute heat stress-induced alterations in blood acid-base status and skeletal muscle membrane integrity in broiler chickens at two ages:implications for meat quality. Poultry Science 2001;80(4):418-425.

Tang S, Yin B, Xu J, Bao E. Rosemary Reduces Heat Stress by Inducing CRYAB and HSP70 Expression in Broiler Chickens. Oxidative Medicine and Cellular Longevity 2018;7014126.

Tang S, Yu J, Zhang M, Bao E. Effects of different heat stress periods on various blood and meat quality parameters in young Arbor Acer broiler chickens. Canadian Journal of Animal Science 2013;93:453- 460.

Wanda MH, Colin GR. Toxicologic pathology: an introduction. 3rd ed. London: Academic Press; 2013. p.1-9.

Ward MA, Peterson RA. The effect of heat exposure on plasma uric acid, lactate dehydrogenase, chloride, total protein and zinc of the broiler. Poultry Science 1973;52(4):1671-1673.

Yalçin S, Bruggeman V, Buyse J, Decuypere E, Cabuk M, Siegel P. B. Acclimation to heat during incubation:4. Blood hormones and metabolites in broilers exposed to daily high temperatures. Poultry Science 2009;88(9):2006-2013.

Zhang M, Bao E. Effects of different heat stress periods on various blood and meat quality parameters in young Arbor Acer broiler chickens. Canadian Journal of Animal Science 2013;93:453-460.

\section{LIST OF ABBREVIATIONS}

\section{CK: Creatine kinase}

LDH: Lactate dehydrogenase

TM: Thermal manipulation

TM1: Thermal manipulation group 1

TM2: Thermal manipulation group 2

TM3: Thermal manipulation group 3

TM4: Thermal manipulation group 4

ED: Embryonic day

${ }^{\circ} \mathrm{C}$ : Degrees Celsius

mRNA: Messenger ribonucleic acid

$\mu \mathrm{l}$ : Microliter

$\mathrm{RH}$ : Relative humidity

RT-PCR: Reverse transcription PCR

GAPDH: Glyceraldehyde-3-phosphate dehydrogenase ACTA1: Alpha $(\alpha)$-actin

ANOVA: Analysis of variance 